\title{
INFLUENCE OF PRIMARY OPEN ANGLE GLAUCOMA SURGERY ON STRUCTURAL AND FUNCTIONAL PARAMETERS OF THE OPTIC NERVE AND ITS ASSOCIATION WITH THE LEVEL OF ATRIAL NATRIURETIC PEPTIDE
}

Summary of the Doctoral Thesis for obtaining the degree of a Doctor of Medicine Specialty - Medicine 


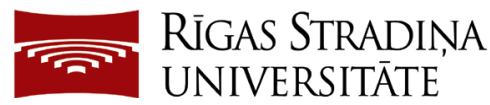

Kristīne Baumane

\section{INFLUENCE OF PRIMARY OPEN ANGLE GLAUCOMA SURGERY ON STRUCTURAL AND FUNCTIONAL PARAMETERS OF THE OPTIC NERVE AND ITS ASSOCIATION WITH THE LEVEL OF ATRIAL NATRIURETIC PEPTIDE}

Summary of the Doctoral Thesis for obtaining the degree of a Doctor of Medicine

Specialty - Medicine

Riga, 2019 
The Doctoral Thesis was carried out at Rīga Stradiņš University.

Scientific supervisor:

Dr. med., Professor Guna Laganovska,

Rīga Stradiņš University, Latvia

Scientific advisor:

Dr. med., Professor Aivars Lejnieks,

Rīga Stradiņš University, Latvia

Dr. biol., Associated Professor Renāte Ranka,

Rīga Stradiņš University, Latvia,

Latvian Biomedical Research and Study Centre

Official reviewers:

Dr. biol., Assistant Professor Kalvis Brangulis,

Rīga Stradiňš University, Latvia,

Latvian Biomedical Research and Study Centre

Dr. med., Professor Ingrida Januleviciene,

Lithuanian University of Health Sciences

Dr. med., Assistant Professor Rimvydas Ašoklis,

Vilnius University, Lithuania

Defence of the Doctoral Thesis will take place at the public session of the Doctoral Council of Medicine on 12 December 2019 at 16.00 in Hippocrates Lecture Theatre, 16 Dzirciema Street, Rīga Stradiṇš University.

The Doctoral Thesis is available in the RSU library and at RSU webpage: www.rsu.lv.

Secretary of the Doctoral Council:

Dr. med., Assistant Professor Gunta Sumeraga 


\section{CONTENTS}

INTRODUCTION

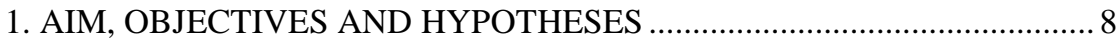

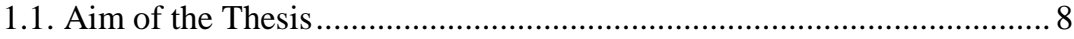

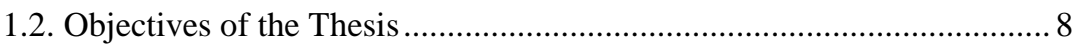

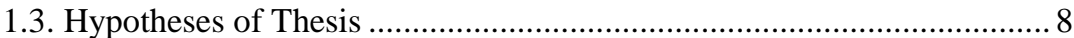

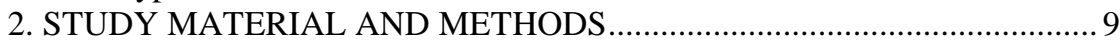

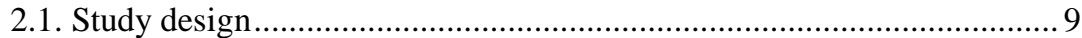

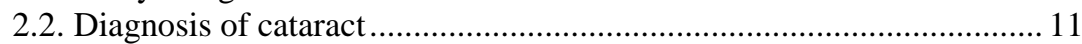

2.3. Tonometry - intraocular pressure measurement .................................... 11

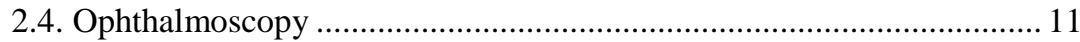

2.5. Optical coherence tomography ………………................................... 12

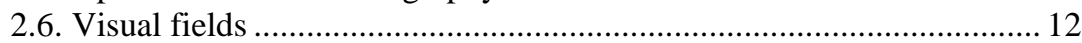

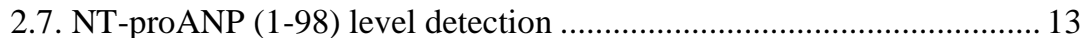

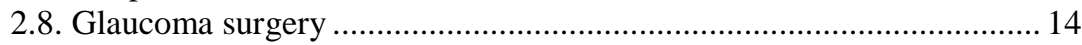

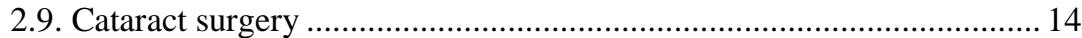

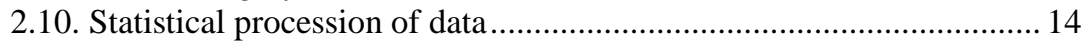

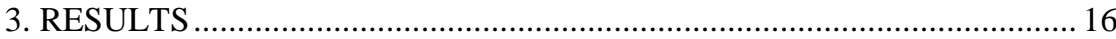

3.1. Influence of trabeculectomy on structural and functional parameters of

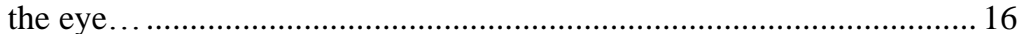

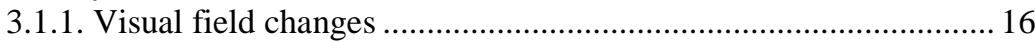

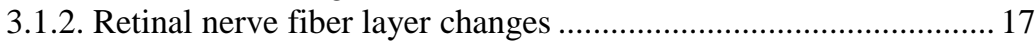

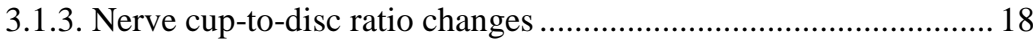

3.2. Changes of atrial natriuretic peptide in intraocular fluid....................... 20

3.2.1. Sensitivity and specificity of NT-proANP in glaucoma ................22

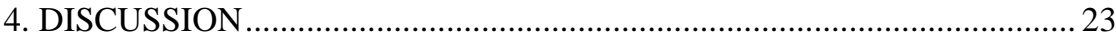

4.1. Influence of glaucoma surgery on functional and structural parameters

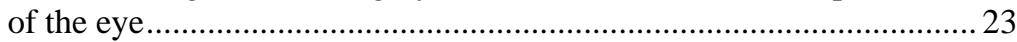

4.2. Role of natriuretic peptides in pathogenesis of primary open-angle

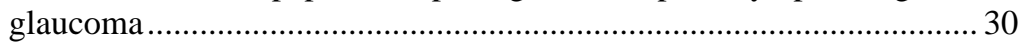

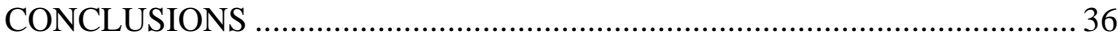

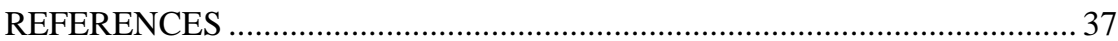

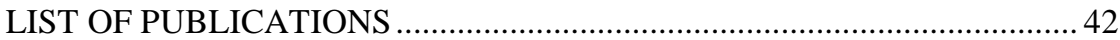

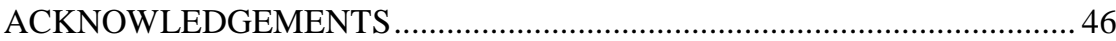




\section{LIST OF ABBREVIATIONS}

ANOVA
ANP
USA
AUC
BNP
cGMP
C/D
MD
NO
NP
NPV
NT-pro ANP
OCT
$p$
POAG
PPV
PSCUH
RNFL
ROC
ROCK
SD
sGC
NCMEHWA

analysis of variance

atrial natriuretic peptide

United States of America

area under the curve

brain natriuretic peptide

cyclic guanosine monophosphate

cup-to-disc ratio

mean deviation

nitric oxide

natriuretic peptide

negative predictive value

$\mathrm{N}$-terminal proatrial natriuretic peptide

optical coherence tomography

calculated probability value

primary open angle glaucoma

positive predictive value

Pauls Stradins Clinical University Hospital

retinal nerve fiber layer

receiver-Operational characteristic curve

rho kinase

standard deviation

soluble guanylate cyclase

National Commission for Medical Expertise on Health and Work Ability 


\section{INTRODUCTION}

Glaucoma is an eye disease, which accounts for $2-10 \%$ individuals above the age of 50 years, and it takes the main place as a cause for irreversible blindness. Primary open-angle glaucoma (POAG) is the most common form of aging-related disease. The primary and most important risk factor for glaucoma is elevated intraocular pressure above the normal range (normal $10-21 \mathrm{mmHg}$ ). Other important risk factors are genetic predisposition, age, sex, race, as well as cardiovascular diseases and diabetes (Liu et al., 2014).

With every year in the world, including Latvia, the number of patients is getting higher. So, in 2010 an average of 60.5 million people in the world suffered from glaucoma (Quigley and Broman, 2006), but in 2013 the number of patients increased to 64.3 million; the number of patients expected in 2020 is 76 million, but in 2040 it will reach an average of 111.8 million (Tham et al., 2014). The increase in the number of patients both in the world and in Latvia should be related to the rise in the average life expectancy of the population, which in Latvia according to the data of the Central Statistical Bureau has increased by an average of 5 years in the last 18 years (Centrālā statistikas pārvalde, 2018). There is no glaucoma registry in Latvia, which is why a precise number of glaucoma patients is unknown. The incidence of the disease is increasing in the world and Latvia: the prevalence of glaucoma in the world averaged 2.65 \% in 2010 (Quigley and Broman, 2006), while in 2014, Tham and co-authors estimated that global glaucoma prevalence was $3.54 \%$ (Tham et al., 2014). Indirectly on the increase in the incidence of the disease, in Latvia it can be judged from the data of the State Agency of Medicines, evaluating the defined daily dose (DDD) of medicines over the period from 2013 to 2017. The data show that in $20130.18 \%$ of the population of Latvia consumed one therapeutic dose of glaucoma medication, whereas in 2017 the number of this population had increased to $0.22 \%$. (Zāḷu valsts aǵentūra, 2018) 
The most common forms of POAG are related to age - these forms start in middle-age, progress slowly but continuously. The course of the disease is invisible, as central vision is usually maintained up to the advanced stage of glaucoma. The disease may not be diagnosed in a long time unless an ophthalmologist is visited. Thus, patients do not start treatment promptly, which could help to preserve vision and avoid irreversible loss of sight (Fernandez et al., 2010). There are often situations, when a patient consults a doctor too late, when the disease is already in the advanced stage. Vision functions are lost irreversibly, and to bring them back or improve them is not possible anymore. Also, in Latvia this problem is very topical. Patients visit a doctor very often in the advanced stages of the disease, and there is no national screening system for early glaucoma diagnosis. From this it can be concluded that there are still many undiagnosed glaucoma cases in Latvia, and all the necessary resources have to be invested in order to achieve timely diagnosis of the disease. Glaucoma is a disease that has a significant personal, social, and economic impact. According to the data of the $9^{\text {th }}$ National Commission for Medical Expertise on Health and Work Ability (Ausekle, 2015), the number of first-time visually impaired people increases every year due to glaucoma.

Reducing intraocular pressure in glaucoma treatment is the main and only proven method of treatment so far (Quigley and Broman, 2006). Treatment of glaucoma starts with locally used medications. If intraocular pressure with medical therapy is not lowered enough, and the target intraocular pressure is not reached, by which the progression rate of the disease would allow maintaining patients sight functions for the estimated overall life expectancy, then a laser treatment or surgery is applied. A surgical treatment method is also used when, despite reduced eye pressure, a progression of the disease is observed, or other methods do not apply to the patient (poor compliance or side effects from topical medications). Surgical approach is also indicated in cases where high eye pressure is already present at the time of detection in the case of advanced 
glaucoma, and it is predictable that other treatment methods will not produce the desired effect (European Glaucoma Society, 2014). In practice and clinical trials, reduction of intraocular pressure by a surgical method has been shown to affect the rate of progression of glaucoma (Bertrand et al., 2014). Surgical treatment may improve structural (Sarkar et al., 2014; Irak et al., 1996) and functional parameters of the eye (Bertrand et al., 2014).

There are very few studies on the effect of glaucoma surgery on structural and functional characteristics of the eye in various stages of glaucoma, and the results obtained are contradictory. Cases where disease progression continues even at fully compensated, reduced intraocular pressure are known. Approximately $1 / 3$ of patients after surgical intraocular pressure reduction over the next five years slowly progresses to both structural and functional glaucomatous changes (Kotecha et al., 2009). This confirms the multifactorial nature of glaucoma, emphasising the eye pressure is not the only factor affecting the progressive neuropathy of the optic nerve. Both humoral and genetic factors can influence the results of glaucoma treatment. Therefore, it is essential to identify any factors that affect the outcome of the treatment and use this knowledge as much as possible to achieve the best possible treatment result.

Although there have been significant studies and discoveries in pathogenesis of glaucoma in recent years, there is still a great deal of uncertainty about the direction in which to continue examinations and seek significant relationships (Knepper et al., 2016). One such trend is detection of atrial natriuretic peptide (ANP) receptors in the eye (Diestelhorst and Krieglstein, 1989; Goldmann and Waubke, 1989) and monitoring of elevated ANP levels in intraocular fluid in glaucoma patients (Salzmann et al., 1998). 


\section{AIM, OBJECTIVES AND HYPOTHESES}

\subsection{Aim of the Thesis}

The aim of the study is to investigate the effect of primary open-angle glaucoma surgical treatment on functional and structural parameters of the eye and to evaluate the role of ANP in pathogenesis of glaucoma.

\subsection{Objectives of the Thesis}

1. To determine the effect of glaucoma surgery on functional parameters of the eye, evaluating changes in the visual field examination in patients with different stages of POAG.

2. To assess the effect of glaucoma surgery on structural parameters of the eye thickness of the retinal nerve fiber layer and nerve c/d ratio in patients with different stages of POAG.

3. To determine changes in the level of NT-pro ANP in plasma and anterior chamber fluid in POAG and cataract patients (as a control group) and assess whether there is any relationship between them.

\subsection{Hypotheses of Thesis}

1. Glaucoma surgical treatment - reduction of intraocular pressure by trabeculectomy method - improves eye function: mean deviation of the visual field decreases.

2. Glaucoma surgical treatment - reduction of intraocular pressure by trabeculectomy - improves structural characteristics of the eye: thickness of the RNFL increases, vertical and horizontal dimensions of the $\mathrm{C} / \mathrm{D}$ ratio decrease.

3. ANP plays a role in POAG pathogenesis: as the rate of glaucoma progresses, the level of ANP increases in anterior chamber fluid. 


\section{STUDY MATERIAL AND METHODS}

\subsection{Study design}

Two separate studies were conducted. Both studies included glaucoma patients who needed traditional trabeculectomy in one eye due to the progression of glaucoma process and low intraocular pressure using medical therapy. Patients were stationed in the PSCUH Department of Ophthalmology for glaucoma surgery.

In the first study, which was held from April 2, 2007 till June 19, 2007, overall 96 glaucoma patients (96 eyes) were included, to whom functional and structural changes before and after glaucoma surgery were assessed. Patients were assigned for trabeculectomy surgery with metabolites during operation for PSCUH Department of Ophthalmology in terms of the progression of glaucoma and insufficiently low intraocular pressure with drug therapy.

Patient inclusion criteria:

1) a patient with uncompensated primary open-angle glaucoma;

2) a patient over 18 years of age;

3) intraocular pressure > $30 \mathrm{mmHg}$;

4) the need to perform first-time glaucoma surgery;

5) clear optical media;

6) a patient who has signed a written consent form to participate in the study.

Patient exclusion criteria:

1) serious intraoperative or postoperative complications;

2) postoperative intraocular pressure $>18 \mathrm{mmHg}$;

3) unclear optical media.

Patients included in the study were divided into three groups based on the availability and reliability of the data obtained. From the obtained 
measurements, the leading indicators characterising structural and functional changes of the eye were selected: mean deviation of the visual field (MD), retinal nerve fiber layer (RNFL), optic nerve cup-to-disc ratio (c/d ratio) and intraocular pressure. All parameters were obtained up to one week before the surgery and one month (30-40 days) after successful glaucoma surgery. Successfully performed glaucoma surgery was defined as an eye without any general signs of inflammation, absence of any postoperative complications, and intraocular pressure $<18 \mathrm{mmHg}$ without medical therapy.

In the second study, which was held from April 22, 2011 till June 14, 2011, overall 58 glaucoma patients (58 eyes) to whom a surgical glaucoma treatment was necessary and 32 cataract patients (32 eyes), to whom a cataract surgery was required were included. Two patient groups were established: a study group of 58 patients with POAG and a control group of 32 patients with cataract. Unilateral surgery was performed in all patients in both patients groups. Before each operation, a blood plasma sample was obtained to determine the level of NTpro-ANP in the blood plasma. During surgery, a sample of anterior chamber fluid was obtained to assess the level of NTproANP in the eye.

\section{Patient inclusion criteria:}

1) a patient with uncompensated primary open-angle glaucoma;

2) a patient over 50 years of age;

3) absence of any other abnormal eye conditions such as uveitis, neovascularisation of the iris, secondary glaucoma;

4) absence of any prior intraocular surgery, including laser therapy;

5) a patient who has signed a written consent form to participate in the study.

Patient exclusion criteria:

1) dibetes mellitus;

2) patients with clinical symptoms of heart failure. 
Patients were informed about the course of the study, and each patient received an individual consent form, which was confirmed by the patient's signature. To realise the clinical study, permission of PSCUH Development society clinical research ethics committee was received.

\section{Diagnosis of cataract}

Diagnosis of cataract was confirmed by examining a patient with a slit lamp biomicroscopy. For all patients, a full ophthalmological examination was performed.

\subsection{Tonometry - intraocular pressure measurement}

Intraocular pressure indices were obtained while a patient was in a sitting position. The same medical practitioner did all measurements. To measure the intraocular pressure, Goldman applanation tonometry method was applied. Tonometry was performed for every patient before and after the surgery. Tonometry was done with Goldman applanation tonometer. During the procedure where with a biprism tonometer head illuminated by blue light touches anesthetised corneal surface flattening it, it measures the force with which this corneal flattening occurs. The method is based on extrusion of approximately 0.5 microliters of tear film liquid at the point when the surface of the contact area reaches $3.06 \mathrm{~mm}$ in diameter.

\subsection{Ophthalmoscopy}

Patients were examined with an indirect ophthalmoscopy method. A slit lamp biomicroscopy and double spheric, condensing lens (Superfield lens (Volk)), which shows the converse, a real image were used. During ophthalmoscopy, the optic nerve was visualised, evaluating optic nerve disc 
colour, size, sharpness of edges, disc excavation and cup-to-disc ratio, neuroretinal rim width in 4 quadrants.

\subsection{Optical coherence tomography}

Thickness of the retinal nerve fiber layer in glaucoma patients was analysed in four quadrants - upper, lower, nasal un temporal - and vertical and horizontal c/d ratio was assessed before glaucoma surgery and one month after glaucoma surgery, using Zeiss optical coherence tomograph Stratus OCT version 4.0.5 (Carl Zeiss Meditec Ophthalmic Systems inc., Dublin, CA, USA). The author of this study took all the measurements. The patient was examined after dilatation of the pupil when it was dilated at least $5 \mathrm{~mm}$ in diameter. RNFL thickness was assessed during one scan three times, scanning 256 points, which are aligned in circumferential line at $3.4 \mathrm{~mm}$ distance from the center of the optic nerve disc. The fast RNFL programme was used, acquiring mean values for RNFL thickness in 12 clock hours, for the thickness of four quadrants and the mean overall RNFL thickness in 360 degrees measurement. Acquired measurements were compared with the OCT-entered normative database derived from percentile values obtained from subjects of a particular age control group.

\subsection{Visual fields}

Visual fields were tested with Centerfield perimeter (OCULUS Optigerräte GmbH, Germany). The data were analysed with the full threshold SITA programme (Swedish Interactive Thresholds Algorithm) with a standardised 30-2 strategy. All included patients had good visual acuity, and previous experience in working with the perimeter (before at least five visual fields were performed with good test credibility). Patients crystal lenses were clear enough not to affect the result, and interpupillary distance was appropriate 
to the requirements of the examination as well (not narrower than three millimeters). Visual fields of eyes, where credibility parameters were beyond the acceptable range of normality (false negative $33 \%$, false positive $33 \%$ and fixation loss $20 \%$ ), were excluded from the analysis. The stage of glaucoma was determined following specific changes in the visual field, using the severity of glaucoma or modified Hodapp-Anderson-Parrish version of the severity staging system (Glaucoma Severity Staging System (GSSS)) (Mills et al., 2006). In all examined test point MD was assessed, which is a difference between standard (age corrected) light perception and a patient retinal light perception. It was determined with the standard automatic perimetry (SAP), using a threshold detection tactic with the double testing tactic.

In the current research, the $2^{\text {nd }}$ stage was defined as an early glaucoma with visual field MD parameters in the range $\leq 6 \mathrm{~dB}$, the $3^{\text {rd }}$ stage as moderately severe glaucoma with MD in the range from $6-12 \mathrm{~dB}$ and the $4^{\text {th }}$ stage as severe glaucoma with MD greater than $12 \mathrm{~dB}$.

\subsection{NT-proANP (1-98) level detection}

Preoperative analgesia of all patients was performed with local surface anesthesia in conjunctival sac using proxymetacaine $0.5 \%$ and subtenonal block, using lidocaine $2 \%$ in combination with bupivacaine $0.5 \%$ in ratio 50:50. Anterior chamber fluid of the eye was taken at the start of glaucoma surgery or cataract surgery with 27 gages anterior chamber cannula through a paracentesis cut. Obtained examples were frozen and stored at $-80{ }^{\circ} \mathrm{C}$ temperature. Blood plasma examples were collected just before the eye surgery and were immediately frozen and stored at $-80^{\circ} \mathrm{C}$ temperature.

The level of NT-proANP (1-98) in the anterior chamber fluid of the eye was assessed using enzyme immunological set proANP ELISA (EnzymeLinked Immunosorbent Assay) (Biomedica Medizinprodukte GmbH\&Co KG, 
Wien, Austria). Following the protocol of the manufacturer, the test was performed in two stages.

\subsection{Glaucoma surgery}

All glaucoma operations were trabeculectomies with the use of mitomycin $\mathrm{C}$ as an antifibrotic agent. All surgeries were performed by the author using the same surgical technique. During the operation in the upper temporal quadrant through a clear cornea, paracentesis was created, through which the anterior chamber fluid example with a 27 caliber anterior chamber cannula was taken. The anterior chamber fluid of the eye was inserted in a special sterile transportable container, which was frozen afterwards and stored in $-80^{\circ} \mathrm{C}$ temperature.

\subsection{Cataract surgery}

For all patients who were included in the study, cataract surgery was performed using phacoemulsification method. All cataract surgeries were performed by the author of this study, using the same surgical method and approach. During the operation, the anterior chamber fluid was evacuated through paracentesis with a 27 caliber anterior chamber cannula, which was then inserted in a special sterile transportable container, frozen and stored in $80{ }^{\circ} \mathrm{C}$ temperature.

\subsection{Statistical procession of data}

Quantitative variables were described by mean arithmetic and standard deviation (SD). Results were expressed as mean \pm SEM (Standard Error of the Mean). Comparison of normally distributed quantitative variables was performed by one-way ANOVA analysis, categorical or qualitative variables 
were compared by Pearson's chi-square test. The independent and paired t-test was used to evaluate the importance when it was needed. $P$ value $<0.05$ was considered to be the threshold for statistical reliability of bilateral tests. Pearson Correlation Analysis was used for two-point correlation analysis. ROC curve analysis was designed to detect the presence or absence of glaucoma using NTproANP levels in intraocular fluid and blood plasma. The area under the curve (AUC) was calculated as well as the $95 \%$ confidence interval. The optimum reference value was determined, and the sensitivity, specificity, positive predictive value (PPV) and negative predictive value (NPV) was calculated using the crosstabs. Statistical processing of the data was performed with $R$ 3.1.1. (Core Team, 2014) programme, GraphPad Software (GraphPad Software Inc., USA) and IBM SPSS statistics programme version 24 (Armonk, NY: IBM Corp., 2016). 


\section{RESULTS}

\subsection{Influence of trabeculectomy on structural and functional parameters of the eye}

For glaucoma patients, three different structural and functional parameters of the eye were analysed: MD, RNFL, and C/D ratio, also changes in intraocular pressure after glaucoma surgery were assessed. In the study, patients with stage 2 (early glaucoma stage), stage 3 (moderately severe stage) and stage 4 (severe glaucoma stage) glaucoma were included.

For all patients who were included in the study, intraocular pressure was lowered when compared to parameters which were obtained preoperatively. One month after the surgery, the mean intraocular pressure was $12.3 \mathrm{mmHg}$. For patients who were included in the study, any severe postoperative complications were not observed.

\subsubsection{Visual field changes}

Changes in visual field mean deviation (MD) of patients were analysed comparing parameters before and one month after the performed glaucoma surgery. The data were obtained from 27 glaucoma patients, from which $51.8 \%$ had stage 2 glaucoma, $26.0 \%$ had stage 3 glaucoma and $22.2 \%$ had stage 4 glaucoma.

The mean MD level before the performed glaucoma surgery was $10.93 \pm$ $4.79 \mathrm{~dB}$, but after the performed glaucoma surgery, the mean MD level was decreased to $9.99 \pm 4.75 \mathrm{~dB}$, although the results had no statistical significance $(p=0.0916)$. When a patient group of each glaucoma stage was analysed separately, an improvement tendency was observed in the level of MD for stage 3 and 4 groups; however, a statistically significant improvement was observed only in the stage 4 patient group. Respectively the mean value of MD for stage 
4 patient group improved from $14.82 \pm 0.29 \mathrm{~dB}$ to $13.24 \pm 2.75 \mathrm{~dB}(\mathrm{p}=$ 0.0482 ). For stage 2 patient group, a small worsening in the value of MD was observed; however, the results were statistically insignificant $(\mathrm{p}=0.7865)$. For stage 2 patient group, a decrease in the MD was observed, by contrast, an improvement tendency of the MD value was assessed for $85.7 \%$ of patients in stage 3 glaucoma, which was not statistically significant. For $71.4 \%$ of stage 4 glaucoma patients, a statistically significant improvement in the MD was observed. Overall, an improvement tendency for the value of MD was observed in $70.4 \%$ of patients - the results are represented in table 3.1 .

Table 3.1.

Mean visual field deviation (MD) after glaucoma surgery

\begin{tabular}{|c|c|c|c|c|c|c|}
\hline \multirow{2}{*}{$\begin{array}{c}\text { Glaucoma } \\
\text { stage }\end{array}$} & \multicolumn{2}{|c|}{ Number of eyes } & \multicolumn{3}{|c|}{ Mean MD value (dB) \pm SD } \\
\cline { 2 - 7 } & $\begin{array}{c}\text { Total } \\
\text { number }\end{array}$ & $\begin{array}{c}\text { Number }(\%) \\
\text { with } \\
\text { improvement }\end{array}$ & $\begin{array}{c}\text { Before } \\
\text { surgery }\end{array}$ & $\begin{array}{c}\text { After } \\
\text { surgery }\end{array}$ & m.d. & $p$ value \\
\hline 2 & 6 & $3(50.0)$ & $\begin{array}{c}3.72 \pm \\
2.08\end{array}$ & $\begin{array}{c}4.19 \pm \\
4.22\end{array}$ & $\begin{array}{c}- \\
0.47\end{array}$ & 0.7865 \\
\hline 3 & 7 & $6(85.7)$ & $9.34 \pm 1.8$ & $\begin{array}{c}8.46 \pm \\
2.36\end{array}$ & 0.89 & 0.1341 \\
\hline 4 & 14 & $10(71.4)$ & $\begin{array}{c}14.82 \pm \\
0.29\end{array}$ & $\begin{array}{c}13.24 \pm \\
2.75\end{array}$ & 1.58 & 0.0482 \\
\hline \multirow{2}{*}{ All stages } & 27 & $19(70.4)$ & $\begin{array}{c}10.93 \pm \\
4.79\end{array}$ & $\begin{array}{c}9.99 \pm \\
4.75\end{array}$ & 0.94 & 0.0916 \\
\hline
\end{tabular}

*SD - standard deviation; m.d. - average difference between two average values

\subsubsection{Retinal nerve fiber layer changes}

The changes in RNFL before and after glaucoma surgery were analysed with the OCT method for 33 patients (11 women and 22 men, average age $68 \pm$ 8 years). Measurements were done in all four quadrants around the optic nerve disc, $3.4 \mathrm{~mm}$ from the center of the disc: in the upper, lower, nasal and temporal quadrant before and after the performed glaucoma surgery. The data were 
obtained from 33 glaucoma patients, from which $27.3 \%$ had stage 2 glaucoma, $51.5 \%$ had stage 3 glaucoma, and $21.2 \%$ had stage 4 glaucoma.

The obtained results showed that the average RNFL thickness does not differ statistically significantly for patients before and one month after surgical glaucoma therapy. Analysing RNFL in each of the four quadrants, a small statistically insignificant RNFL improvement tendency in the upper $(p=0.134)$, temporal $(\mathrm{p}=0.114)$ and nasal $(\mathrm{p}=0.984)$ quadrant was observed (Figure 3.1.). Analysing the obtained results separately for each glaucoma stage group, a statistically insignificant RNFL decrement tendency in all four quadrants was observed for stage 4 patient group.

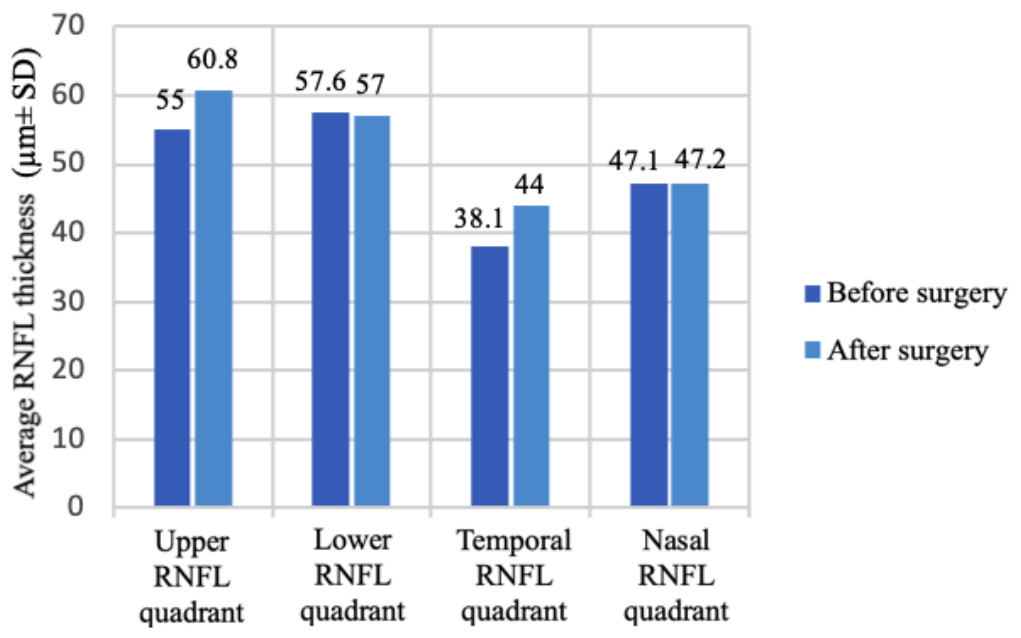

Figure 3.1. Total RNFL changes in four quadrants of the optic nerve disc.

\subsubsection{Nerve cup-to-disc ratio changes}

The optic nerve cup-to-disc ratio was analysed for the study patients before and one month after glaucoma surgery. Overall data from 36 patients with different glaucoma stages were obtained, from which $25 \%$ had stage 2 glaucoma, $52.8 \%$ had stage 3 glaucoma, and $22.2 \%$ had stage 4 glaucoma. The 
cup-to-disc ratio was measured in both directions - horizontally and vertically, and any decrement of this parameter was assessed as an improvement. In total, an improvement tendency was detected in both horizontal and vertical cup-todisc ratio, for $61.1 \%$ and $55.6 \%$ patients respectively. The obtained results showed statistically significant changes in the mean values of the horizontal c/d ratio of the optic nerve after the glaucoma surgery. Respectively parameter improved from $0.84 \pm 0.16$ to $0.81 \pm 0.2$ with the mean decrement of $0.04(\mathrm{p}=$ 0.033). In contrast, any statistically significant changes in the mean values of the vertical $\mathrm{c} / \mathrm{d}$ ratio were not detected $(\mathrm{p}=0.77)$. The obtained results are shown in table 3.2 .

Table 3.2.

The optic nerve cup-to-disc (c/d) ratio after the glaucoma surgery

\begin{tabular}{|c|c|c|c|c|c|c|c|c|c|c|c|}
\hline \multirow[b]{2}{*}{ 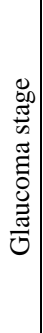 } & \multirow[b]{2}{*}{ 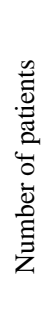 } & \multicolumn{5}{|c|}{ Horizontal c/d ratio } & \multicolumn{5}{|c|}{ Vertical c/d ratio } \\
\hline & & $\begin{array}{l}\vec{D} \\
\stackrel{0}{0} \\
\Xi \\
\vdots \\
0 \\
0 \\
0 \\
0 \\
0\end{array}$ & 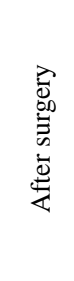 & 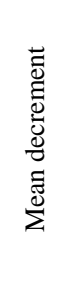 & $\begin{array}{l}\stackrel{0}{Z} \\
\stackrel{\pi}{>} \\
2\end{array}$ & 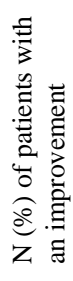 & 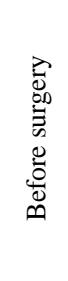 & 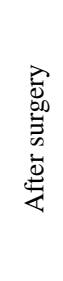 & 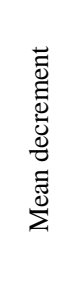 & $\begin{array}{l}\frac{0}{3} \\
\stackrel{\pi}{J} \\
2\end{array}$ & 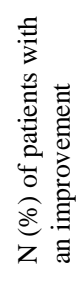 \\
\hline 2 & 9 & $\begin{array}{c}0.63 \\
\pm \\
0.19\end{array}$ & $\begin{array}{c}0.58 \\
\pm 0.2\end{array}$ & 0.05 & 0.09 & $\begin{array}{c}7 \\
(77.8 \\
)\end{array}$ & $\begin{array}{c}0.67 \\
\pm \\
0.18\end{array}$ & $\begin{array}{c}0.67 \\
\pm \\
0.17\end{array}$ & 0.001 & 0.97 & $\begin{array}{c}5 \\
(55.6)\end{array}$ \\
\hline 3 & 19 & $\begin{array}{c}0.90 \\
\pm \\
0.06\end{array}$ & $\begin{array}{c}0.89 \\
\pm \\
0.12\end{array}$ & 0.02 & 0.40 & $\begin{array}{c}9 \\
(47.4 \\
)\end{array}$ & $\begin{array}{c}0.88 \\
\pm 0.8\end{array}$ & $\begin{array}{c}0.88 \\
\pm \\
0.06\end{array}$ & 0.001 & 0.98 & $\begin{array}{c}12 \\
(63.2)\end{array}$ \\
\hline 4 & 8 & $\begin{array}{c}0.94 \\
\pm \\
0.04\end{array}$ & $\begin{array}{c}0.87 \\
\pm \\
0.18\end{array}$ & 0.07 & 0.24 & $\begin{array}{c}6 \\
(75.0 \\
)\end{array}$ & $\begin{array}{c}0.91 \\
\pm \\
0.06\end{array}$ & $\begin{array}{c}0.93 \\
\pm \\
0.05\end{array}$ & -0.02 & 0.43 & $\begin{array}{c}3 \\
(37.5)\end{array}$ \\
\hline 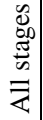 & 36 & $\begin{array}{c}0.84 \\
\pm \\
0.16\end{array}$ & $\begin{array}{c}0.81 \\
\pm 0.2\end{array}$ & 0.04 & 0.03 & $\begin{array}{c}22 \\
(61.1 \\
)\end{array}$ & $\begin{array}{c}0.84 \\
\pm \\
0.15\end{array}$ & $\begin{array}{c}0.84 \\
\pm \\
0.14\end{array}$ & $\begin{array}{c}- \\
0.004\end{array}$ & 0.77 & $\begin{array}{c}20 \\
(55.6)\end{array}$ \\
\hline
\end{tabular}




\subsection{Changes of atrial natriuretic peptide in intraocular fluid}

Changes of atrial natriuretic peptide (ANP) in intraocular fluid were assessed for 58 POAG patients with different glaucoma stages, from which $22.4 \%$ had stage 1-2 glaucoma, $60.3 \%$ had stage 3 glaucoma, and $17.3 \%$ had stage 4 glaucoma. Parallel measurements from the blood plasma examples of these patients were taken. Patients age on average was $72 \pm 8$ years. As a control group, 32 cataract patients were included, where the mean age was $75 \pm$ 9 years. In the study were included only those patients whose surgery went successfully and who in the postoperative period did not develop any severe complications.

When comparing all three glaucoma patient groups, the intraocular pressure was significantly higher in the stage 4 glaucoma patient group (39.20 \pm $12.68 \mathrm{mmHg})$, using the ANOVA method ( $\mathrm{p}=0.0049)$; but in the other two groups - stage 1 to 2 glaucoma and stage 3 glaucoma - the mean intraocular pressure was similar to each other (respectively $28.46 \pm 7.71 \mathrm{mmHg}$ and 28.69 $\pm 8.02 \mathrm{mmHg}$ ) (Figure 3.2. A).

NT-proANP concentration was significantly higher to PAOG patients, when compared to cataract (control) group (respectively 7.00 un $4.65 \mathrm{nmol} / \mathrm{l}$, $\mathrm{p}=0.0054)$ (Figure 3.2.B). 


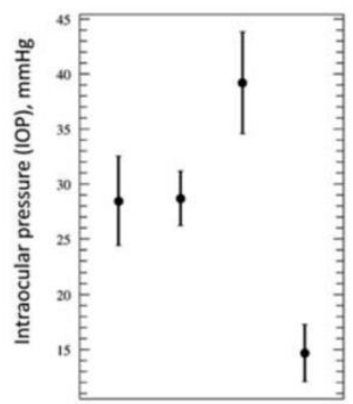

A

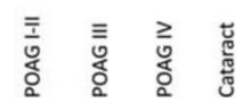

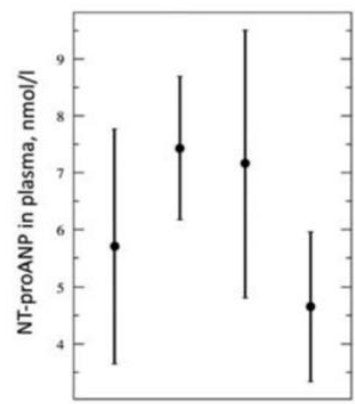

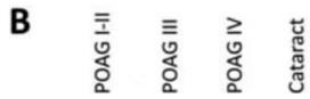

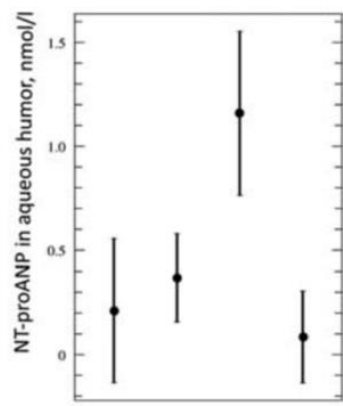

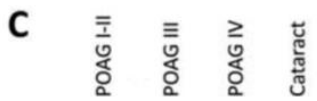

Figure 3.2. Intraocular pressure, NT-proANP concentration in the blood plasma and anterior chamber fluid in glaucoma and cataract patients

NT-proANP level in the blood plasma was compared between different stage glaucoma groups and the control group, using the ANOVA test. Statistically significant difference was found $(\mathrm{p}=0.0210)$. Similarly, also in the anterior chamber fluid, the concentration of NT-proANP was significantly higher than for cataract patients $(0.47$ against $0.09 \mathrm{nmol} / \mathrm{l}, \mathrm{p}=0.0112)$, and the difference was statistically significant comparing different POAG stage groups with the control group $(\mathrm{p}=0.0001)$. The results showed that as POAG progresses from stage $1 / 2$ to stage 4 of POAG, the mean value of NT-proANP level in the intraocular fluid gradually increases (Figure 3.2.C).

Estimating the correlation between different analysed parameters, a statistically significant relationship between the blood plasma and intraocular fluid for NT-proANP level in cataract patients was observed $(\mathrm{R}=0.5465, \mathrm{p}=$ 0.001). Meanwhile, using Pearson's correlation analysis, no correlation was found between the level of NT-proANP in the blood plasma and intraocular fluid for POAG patients $(\mathrm{R}=0.2579 ; \mathrm{p}=0.051)$. No statistically significant association was detected between the intraocular pressure and the NT-proANP level in the blood plasma and intraocular fluid (respectively, $\mathrm{p}=0.800$ and $\mathrm{p}=$ $0.355)$. 


\subsubsection{Sensitivity and specificity of NT-proANP in glaucoma}

When performing ROC curve analysis for the NT-proANP level, a higher NT-proANP resolution ability in intraocular fluid for glaucoma was observed compared to NT-proANP in the blood plasma. As the result of NTproANP ROC analysis in the intraocular fluid, the following data was obtained: AUC 0.865 , sensitivity $88.5 \%$, specificity $72.7 \%$, cut-off value $0.075 \mathrm{nmol} / \mathrm{L}$, $95 \%$ CI 0.784-0.947, PPV 0.857, NPV 0.774 (p < 0.001). When analysing NT-proANP in the blood plasma, the following data was obtained: AUC 0.689, sensitivity $75.4 \%$, specificity $48.5 \%$, cut-off value $3.950 \mathrm{nmol} / \mathrm{L}, 95 \%$ CI 0.575-0.803, PPV 0.730, NPV $0.516(\mathrm{p}=0.003)$ (Figure 3.3.).

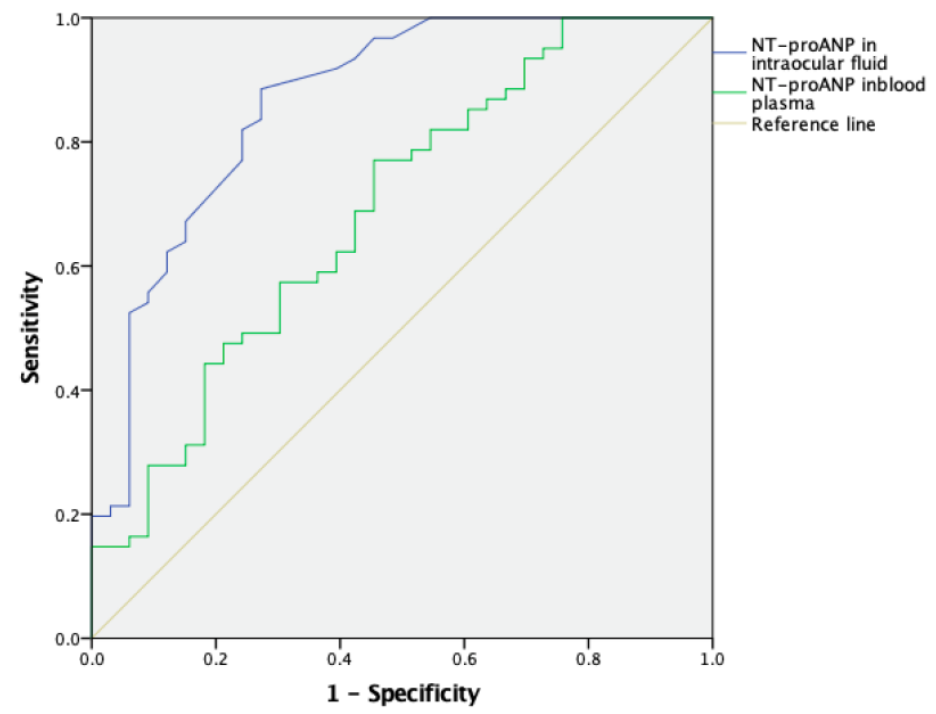

Figure 3.3. ROC curve analysis for NT-proANP in the intraocular fluid and blood plasma in the case of glaucoma 


\section{DISCUSSION}

\subsection{Influence of glaucoma surgery on functional and structural parameters of the eye}

Precise examination of the optic nerve disc, retinal nerve fiber layer, and visual functions is essential for both determination of the stage of glaucoma and rate of progression of the disease. However, it is little known what the possible changes in these parameters are when successful glaucoma surgery results in a significant and rapid reduction in intraocular pressure. There are publications (Panda-Jonas et al., 2014; Yuen et al., 2010) that confirm the positive effects of successful glaucoma surgery on morphological changes in the optic nerve. In the current study, changes in the mean deviation (MD) of the visual field for POAG patients were analysed before and one month after glaucoma surgery. Results showed an improvement tendency in the MD of the visual field after the surgery, but a statistically significant improvement of the MD was observed only for patients with stage 4 glaucoma $(\mathrm{p}=0.0482$ ). This confirms that it is also essential to carry out glaucoma surgery in the late stages of glaucoma and to reduce intraocular pressure. Early-stage patients may have experienced visual improvement later than one month after the surgery. It is known that the development and progression of glaucoma are influenced by intraocular pressure, which is the leading risk factor for glaucoma and the only parameter to be treated and affected so far. This assertion is confirmed by both clinical experience and results of many publications by different authors (Heilj et al., 2002; Miglior et al., 2007; Ekstrom, 2012). Also, the research in the Doctoral Thesis showed that reducing intraocular pressure through glaucoma surgical therapy can lead to improvement of the visual field within a month for patients with advanced glaucoma. Glaucoma clinical trials provide convincing evidence,

which approves that reducing intraocular pressure reduces the risk of 
progression of optic neuropathy. Each intraocular pressure $\mathrm{mmHg}$, which is higher (or lower) in dynamics, changes the risk of progression by about $10 \%$ by reducing or increasing it (Leske et al., 2003). Glaucoma surgical treatment has the same function as medical therapy or laser therapy: reducing intraocular pressure in the eyes affected by glaucoma, thereby stabilising eyesight and delaying further loss of visual field. However, studies have shown that surgical treatment is unable to restore the visual field loss due to glaucoma (Lamping et al., 1986). Similarly, the present study confirms that improvement of the visual field was observed only in patients with stage 4 glaucoma $(p=0.0482)$. The number of stage 2 and 3 patients included in our study was half the number of patients in stage 4 . It may be that statistically reliable results would be obtainable by smoothing the number of patients.

Some researchers have observed an improvement of visual functions and structures after glaucoma surgery (Aydin et al., 2003; Raghu et al., 2012; Chang et al., 2007). Raghu et al. have observed short-term fluctuations in changes of the RNFL thickness after glaucoma surgical treatment, detecting a short-term increase of RNFL thickness, which after three months returned in the preoperative level. The increase of RNFL thickness could be explained with postoperative edema. In contrast with this observation, Rebolleda et al. research, as well as Topouzis et al. did not find any significant changes in these parameters of the eye six and eight months after glaucoma surgery (Rebolleda et al., 2007; Topouzis et al., 1999). Similar results were obtained in a research done for 11 operated glaucoma patients by Wittström (Wittström et al., 2010). Wittström performed visual field and OCT examination for her patients two and six months after surgery. The results of these examinations did not show a significant difference between preoperative and postoperative outcomes. In turn, in additionally performed multifocal electroretinography an improvement of the central retinal functions was detected six months after the surgery. In our research measurements of the RNFL were done in all four quadrants around the 
optic nerve disc: upper, lower, nasal, and temporal quadrant. Results showed that the average RNFL thickness did not differ statistically significantly before and one month after surgical therapy. These results match with the research carried out by Raghu et al. and confirms that glaucoma surgical treatment does not fundamentally impact RNFL thickness.

In association with the positive changes in c/d ratio after successful glaucoma surgery, experimental research showed that reversion of the excavation is more possible in the early stages of glaucoma (Coleman et al., 1991). In the study of the Doctoral Thesis, an improvement tendency of horizontal and vertical C/D ratio one month after surgery was detected in 61.1 $\%$ and $55.6 \%$ respectively. The observed changes in the research were statistically significant for the horizontal $\mathrm{c} / \mathrm{d}$ ratio $(\mathrm{p}=0.03)$; however, results for the vertical c/d ratio did not reach a statistical significance. Recent studies claiming that it is essential to reduce intraocular pressure aggressively suggest that patients should be recommended to undergo glaucoma surgery as soon as possible. In few types of research, it is recommended to perform glaucoma surgery earlier, for example, for patients with normal or low-pressure glaucoma, patients who are significantly uncollaborative, as well as patients to whom the visual functions are disappearing. The current research indicates that due to glaucoma surgery not only intraocular pressure decreases, which is essential to protect a patient from the progression of neuropathy, but also an improvement tendency of structural and functional parameters of the eye is observable. Although statistically insignificant, a small improvement tendency was detected for stage 2 and 3 glaucoma patients. For patients with stage 4 POAG, statistically significant positive changes were assessed after surgical therapy. Thereby, an immediate surgical intervention would be recommendable in all cases of insufficiently lowered intraocular pressure, when maximal medicamentous treatment has been already used, and functional loss has been confirmed. 
In literature data about the changes of optic nerve disc excavation, it can be found about the decrease of the optic nerve disc excavation after the therapy has been received (Azuara-Blanco et al., 1997), and that it occurs in 6-31\% of cases (Lesk et al., 1999; Parrish et al., 2009; Katz et al., 1989; Kotecha et al., 2001). Evidence suggests that it correlates with a decrease in intraocular pressure (Azuara-Blanco, 1997; Lesk et al., 1999; Parrish et al., 2009). AzuaraBlanco et al. mention six possible mechanisms which could affect the $\mathrm{c} / \mathrm{d}$ ratio. They are mechanical movement of tissues, extravascular fluid accumulation, tissue proliferation, optical illusion (pseudoreversion contrariwise to real excavation reversion), tissue decompression, changes in the optic nerve disc blood flow (Azuara-Blanco et al., 1997). However, there are conflicting research findings whether functional improvement is associated with reversion of the disc excavation. CIGTS (Collaborative Initial Glaucoma Treatment Study) did not detect improvement of visual field or visual acuity (Parrish et al., 2009), while other studies confirm improvement of the visual field and RNFL thickness (Kotecha et al., 2001; Park et al., 1997; Harju et al., 2008).

In a research about cases of morphological changes of the optic nerve disc in younger adults (mean age $28.7 \pm 6$ years) with glaucoma after reduction of intraocular pressure with the help of glaucoma surgery, Panda-Jonas with co-authors reported about a new finding in the changes of the optic nerve sizes (Panda-Jonas et al., 2014). In contrast, previous large-scale hospital studies did not reveal a significant difference in the disc size between healthy subjects and glaucoma patients. (Jonas et al., 1989; Quigley et al., 1999). Possible causes of discrepancies between the studies could be related to the age of patients included in the study. The data obtained by Panda-Jonas and co-authors coincide with Poostchi et al. data that showed that transient experimental increase in intraocular pressure up to $64 \mathrm{mmHg}$ for less than 30 seconds in the eyes of an adult causes a small $(3.89 \%)$, but significant ( $<$ 0.0001) increase in the area of the optic nerve disc and linear size of the disc (Poostchi et al., 2010). 
These results are not also inconsistent with the results of a study by Nicolela and co-authors (Nicolela et al., 2006) that did not reveal changes in the optic nerve topography after a moderate elevation and reduction of the intraocular pressure of $5 \mathrm{mmHg}$, which are too small pressure fluctuations.

Results that confirm the decrease of the size of the optic nerve disc for patients with glaucoma after a pronounced high intraocular pressure reduction could be similar to the finding when in cases of experimental glaucoma for chimpanzees an increase in the size of the optic nerve disc was detected (Yang et al., 2011). Findings in the research of Panda-Jonas allow us to talk about many observations which affect the optic nerve in younger glaucomatous eyes after decrement of the intraocular pressure. Observations that some eyes can react with the decrement in the optic nerve disc diameter allow for the conclusion that tissues on the edge of the optic nerve disc have preserved their elasticity; therefore, decrement of intraocular pressure is associated with a small disc size reduction. Since there is a known correlation between the size of the optic nerve disc and the size of the optic nerve disc excavation, decrement of the disc causes a secondary reduction of the optic nerve disc excavation and $\mathrm{c} / \mathrm{d}$ diameter ratio. It is not fully understood why in some eyes decrement of the disc size appears and which factors affect this process. Some authors believe that it is directly related to the amount and time of reduced intraocular pressure in what it is done. Other authors, on the other hand, consider that the main factors might be the length of time during which the eye was exposed to increased intraocular pressure, the resulting postoperative intraocular pressure, and the age of the patient (Panda-Jonas et al., 2014). Dissertation changes in the optic nerve disc parameters caused by decreased eye pressure as a result of glaucoma surgery were analysed gathering data on its decline. The obtained data confirm that intraocular pressure reduction has a positive effect on such optic nerve parameters as the horizontal optic nerve disc excavation. In this study the amount and time of reduced intraocular pressure were not studied; 
that is, the length of time the eye having been exposed to increased intraocular pressure before the surgery, and whether it has had an effect. In the current research, the mean age of the studied population was $68 \pm 8$ years, which differed essentially from the mean age of the research group in the study done by Panda-Jonas. It is possible that a greater mean age of patients in the current study was the reason why the expected decrease of excavation was not detected also in the vertical optic nerve c/d ratio.

In this study, magnitude and changes of parapapillary atrophy of the optic nerve disc were not measured, while other authors analysed the size and alterations of this area, considering the changes in this area as significant, and characteristic signs of glaucoma progression and possible regression. Reasons for the decrease in size of the parapapillary atrophy beta zone are not clear (Panda-Jonas et al., 2014). Some authors consider that the factors influencing the parameters of the optic nerve disc also affecting the reduction of the beta zone. The fact that decrease in postoperative intraocular pressure results in a significant increase in the area of the neuroretinal border and returns to its standard shape has been described earlier. After recent studies with OCT measuring the distance from the Bruch's membrane opening to the internal limiting membrane to determine its applicability to early glaucoma stage diagnosis (Panda-Jonas et al., 2014), it was concluded that this method is not accurate in the eyes with physiologically deep optic nerve excavation as well as Bruch's membrane aperture-minimum edge width analysis does not correlate with existing visual field defects and circumpapillary RNFL analysis, possibly due to axonal convergence of the optic nerve disc. According to clinical studies of the optic nerve disc glaucomatous damage, where an OCT was used, the Bruch's membrane does not reach the border of the optic nerve disc in all eyes (Lee et al., 2010; Na et al., 2010; Manjunath et al., 2011; Reis et al., 2012). Mostly, the Bruch's membrane does not reach the border of the optic nerve disc on the temporal side of the optic nerve, especially in eyes with moderate degree 
nearsightedness. It is not possible to define alpha and beta zones in such eyes, in such cases, one talks about gamma zone. Theoretically, the authors believe that the location of the posterior aperture of the Bruch's membrane is identical to the size and shape of the optic nerve disc. In the case of moderate myopia, when a prolonged axis of the eyeball develops, an increase of the Bruch's membrane aperture is observable, while the optic nerve disc itself does not change significantly. In this temporal parapapillary region of the optic nerve, where there is no Bruch's membrane, the so-called sliding Bruch's membranes concept works. The Panda-Jonas research discovery of changes in the optic nerve disc parapapillary area supports this sliding Bruch's membrane concept. After lowering the intraocular pressure, the Bruch's membrane can slide back closer to the edge of the optic nerve that causes changes in the size of the optic nerve parapapillary atrophy in the OCT. Further research is needed to investigate changes in the optic nerve parapapillary area associated with the reduction of intraocular pressure by the OCT method.

A diagnostic feasibility study in which glaucoma patients and healthy control group patients of similar age were examined by SD-OCT confirmed that these optic disc parameters can distinguish between healthy and glaucoma eyes as well as measurements of the retinal nerve fiber layer thickness (Mwanza et al., 2011). However, another study with glaucoma, pre-perimetric glaucoma, and healthy control subjects demonstrated that determining thickness of the retinal nerve fiber layer better confirms the difference between the investigated groups than the determination of the optic nerve disc parameters. (Sung et al., 2012). The contradictory results of these two studies may be due to inclusion and analysis of glaucoma patients with different stages of glaucoma: in one study with early glaucoma and the other with pronounced glaucoma. Although the data from both studies in cases of pronounced glaucoma coincide - OCT has similar diagnostic capabilities in determining the neuroretinal rim area and the average thickness of the retinal nerve fiber layer. Analysis of SD-OCT 
optic nerve disc parameters in the case of glaucoma diagnosis is still to be investigated.

The research carried out confirms that thickness of the retinal nerve fiber layer is the diagnostically most accurate parameter for diagnosis of glaucoma. Several studies assess diagnostic capabilities obtained by examing and analysing individual macular and optic nerve disc parameters whose diagnostic significance is comparable to the retinal nerve fiber layer examination. Various retinal nerve fiber layer thickness measurements from different SD-OCT examinations have been reported, linked to the difference in optical capabilities and segmentation algorithms between different devices. This means that measurements made with various OCT equipments are not comparable to each other and a patient should be tested in dynamics with the same equipment used for previous investigations (Pierro et al., 2012). However, although such differences exist, all OCT equipment has similar diagnostic capabilities (Akashi et al., 2013). In the current study, the same OCT method used provided an opportunity to analyse dynamics of the retinal nerve fiber layer (RNFL) and cup-to-disc ratio changes precisely at the same site, which allowed to successfully evaluate the influence of glaucoma surgical treatment on structural parameters of the eye. The aim of the Doctoral Thesis was not to assess the usefulness of RNFL and C/D measurements as diagnostic parameters, therefore the diagnostic abilities of these indicators were not analysed.

\subsection{Role of natriuretic peptides in pathogenesis of primary open- angle glaucoma}

Presence of natriuretic peptides in ocular tissues, their ability to affect vascular tone and reduce intraocular pressure confirm that they play a significant role in POAG pathogenesis. Also, interactions have been observed and confirmed as well as relationship between cardiovascular function and risk 
factors and development and progression of many eye diseases, including glaucoma (Flammer et al., 2013). The study carried out in the Doctoral Thesis found a correlation between the level of NT-proANP in blood plasma, in anterior chamber fluid and POAG. In blood plasma and anterior chamber fluid, the concentration of NT-proANP was significantly elevated in the POAG patient group compared to the cataract (control) patient group. In addition, the average level of NT-proANP concentration in anterior chamber fluid was found to vary between the stages of glaucoma and gradually increasing as the disease progressed. Progressing the POAG from POAG stage 2-3 to stage 4, the mean values of the NT-proANP level in anterior chamber fluid gradually increased, respectively, the mean value of the NT-proANP level in the anterior chamber fluid was $0.21 \pm 0.18$ for stage $2-3$ and $1.16 \pm 1.78$ for stage $4(\mathrm{p}=$ 0.0001). Difference between stages 3 and 4 in the NT-proANP concentration level in anterior chamber fluid was observed for the POAG patients, but the NT-proANP level in the blood plasma was practically the same for the exact glaucoma stage patient groups. This observation is reinforced by the fact that in POAG patients, the correlation between the level of NT-proANP in blood plasma and anterior chamber fluid was not statistically significant $(\mathrm{p}=0.0506)$ compared to cataract patients for whom this correlation was statistically significant $(\mathrm{p}=0.0012)$.

Several studies have demonstrated the role of natriuretic peptides, including the role of atrial natriuretic peptide in regulation of intraocular pressure through cGMP pathway. It has been found that the cGMP pathway by activating protein kinase causes inhibition of ROCK, resulting in smooth muscle relaxation and relaxation of trabecular meshwork, which improves intraocular fluid outflow (Quigley et al., 2000; Wareham et al., 2018; Tanna and Johnson, 2018; Kotikoski et al., 2002, 2003). The results obtained in the Doctoral Thesis could indicate a compensatory increase of ANP to increment of intraocular pressure, as the glaucoma process progresses, which is also 
confirmed by results obtained in other clinical studies with both humans and experimental animals (Fernandez-Durango et al., 1999; Goldman et al., 1989; Wolfensberger et al., 1994). Such statistically significant increase of ANP in intraocular fluid allows to promote the NT-proANP as a possible glaucoma biomarker. So far, there have not been many studies in which the ANP would be identified as a possible glaucoma biomarker. In the study done by Salzmann et al., the level of ANP and BNP was assessed in anterior chamber fluid for the first time in humans, compared with each other between glaucoma and control group (cataract) patients. The study found that ANP levels in glaucomatous eyes tend to be higher than in the control group (Salzmann et al., 1998). In the research of the Doctoral Thesis, analysis of the ROC curve was performed for the level of NT-proANP in intraocular fluid and blood plasma. NT-proANP in intraocular fluid was identified as a good resolution biomarker in the case of glaucoma. The obtained AUC was 0.865 with sensitivity of $88.5 \%$, specificity $72.7 \%$, assessed cut-off value of $0.075 \mathrm{nmol} / \mathrm{L}$ ( $\mathrm{p}<0.001$ ). In turn, the level of NT-proANP in the blood plasma was with lower sensitivity and specificity (accordingly $75.4 \%$ and $48.5 \%, \mathrm{p}=0.003$ ). In many studies it has been detected, that potential candidates for POAG biomarkers are such molecules which take part in changes of trabecular meshwork extracellular matrix, promoting trabecular meshwork matrix synthesis, degradation, and modification. However, the acquisition of intraocular fluid samples is referred to as a highly invasive procedure that requires surgical approach (Duan et al., 2008; Alvarado et al., 2005; Fuchshofer and Tamm, 2009). The above explains the situation why in the literature there are not widely available studies about biomarkers in anterior chamber fluid for POAG. Studies conducted so far have concluded that glaucoma biomarkers can be used well in epidemiology, disease prevention, screening, evaluation of the disease progression and effectiveness of the treatment applied (Agnifili et al., 2015). Considering that the ANP is pathogenically related to trabecular outflow pathway and regulation of the 
intraocular fluid outflow resistance, the increase in the NT-proANP level found in the study of the Doctoral Thesis could be attributed directly to the classic POAG process and its progression. The cut-off value of NT-proANP in intraocular fluid in the promotion work was set at $0.075 \mathrm{nmol} / \mathrm{L}$. Identifying the level of NT-proANP in the intraocular fluid above this defined level would be more likely to detect presence of glaucoma.

In the research of the Doctoral Thesis, it is confirmed that the level of NT-proANP in intraocular fluid increases with the degree of glaucoma stage. This observation coincides with the increase of NT-proANP in intraocular pressure when its level compensatory increases to the rise in intraocular pressure. In the study of the Doctoral Thesis, glaucoma patients were included to whom intraocular pressure was not compensated at different stages of glaucoma, with an average intraocular pressure of $28.46 \pm 7.71 \mathrm{mmHg}$ for stage $1-2,28.69 \pm 8.02 \mathrm{mmHg}$ for stage 3 and $39.20 \pm 12.68 \mathrm{mmHg}$ for stage $4(\mathrm{p}=$ 0.0001). Since glaucoma is a progressive neuropathy which continues to progress also with compensated eye pressure (intraocular pressure $<21 \mathrm{mmHg}$ ) (Heijl et al., 2009), further studies should be devoted to the detection of NTproANP level in intraocular fluid in eyes with compensated intraocular pressure, when it could be possible to assess whether the NT-proANP level increases with compensated eye pressure with the glaucoma stage increasing. These measurements could be made during any ophthalmic surgical manipulation, such as cataract surgery or intravitreal drug administration. This would make it possible to determine the progression of the disease more effectively and intensify the treatment used.

Several animal studies have identified several drugs, such as opioid $\mathrm{K}$ receptor agonist (bridazocine) and imidazoline-1 (alpha 2 agonist), which increased the level of ANP in intraocular fluid. It was concluded that the medication-induced release of NP from cellular epithelial cells could modify the level of intraocular pressure as an autocrine or paracrine factor 
(Alexandrescu et al., 2010). In the Doctoral Thesis, relationship between the level of ANP in intraocular fluid and its role in pathogenesis of glaucoma was confirmed. Considering that the treatment of glaucoma should be pathogenically justified, determination of the level of potential glaucoma biomarker NT-proANP in intraocular fluid would allow assessing the degree of disease compensation based on an existing therapy. In recent years, there has been a significant increase in interest in developing a new group of glaucoma drugs. The latest group of antiglaucomatous medications developed in last years are Rho kinase inhibitors, of which only two have been approved for clinical use in Japan and the USA. The neuroprotective activity of the Rho kinase inhibitors, improvement of blood supply to the eye, and antifibrotic action have been demonstrated. Various clinical studies have shown that Rho kinase inhibitors are highly effective as a complementary therapy to already existing classes of antiglaucomatous drug groups, taking into account the different mechanisms of action of Rho kinase inhibitors - reduction of intraocular fluid outflow resistance (Tanna et al., 2018). In a recent study in preclinical models, the ability of the topically used sGC activator MGV354 to reduce intraocular pressure was detected. In connection with this observation, early phase studies have been started to develop intraocular pressure reducing therapy for glaucoma (Buys et al., 2018). In recent studies, effectiveness of NO in reduction of intraocular pressure has been proven. In second and third phase clinical research, effectiveness of antiglaucomatous drug latanoprostene bunod has been detected, where a rapid in situ metabolism of the substance was observed, causing a prostaglandin effect, improving the uveoscleral outflow, and NO effect, lowering resistance in the trabecular meshwork and Schlemm's canal (Wareham et al., 2018). Considering the close pathogenical association of ANP with Rho kinases and NO-sGC-cGMP signaling pathway, further research is needed to evaluate the ANP antiglaucomatous activity and determine the possible medical use. 
Although statistically reliable results were obtained in the study, some of its limitations should be acknowledged. The relatively small number of samples does not allow the results of the study to be generalised. Further studies should include a higher number of samples to be studied, different populations, and different types of glaucoma (closed-angle glaucoma, secondary glaucoma). In conclusion, there is confirmation of a relationship between changes in POAG and NT-proANP levels in intraocular fluid and blood plasma. The data obtained in this Thesis supports the idea of the role of the natriuretic peptide system in the development of POAG and promotes the ANP as a potential glaucoma biomarker. 


\section{CONCLUSIONS}

1. Statistically significant functional changes after the performed glaucoma surgery were identified in POAG patients at stage 4 of the disease. The improvement in functional changes obtained in other POAG stages was not statistically significant. It was concluded that glaucoma surgery at the early stages of POAG had no significant effect on functional parameters of the eye one month after the surgery.

2. Analysing the changes in the structure of the optic nerve, no statistically significant improvement in thickness of the retinal nerve fiber layer in POAG patients was observed after glaucoma surgery. A statistically significant reduction in the horizontal cup-to-disc ratio was identified in POAG patients following glaucoma surgery. It can be concluded that glaucoma surgery affects reduction of the horizontal cup-to-disc ratio one month after the surgery.

3. An increased level of ANP in anterior chamber fluid was detected in POAG patients. A statistically significant correlation between ANP concentration in anterior chamber fluid and the glaucoma stage was identified. NT-proANP has a high-resolution ability in intraocular fluid for glaucoma with a sensitivity of $88.5 \%$, specificity $72.7 \%$, and a cut-off value of $0.075 \mathrm{nmol} / \mathrm{L}$. ANP can be promoted as a potential biomarker for primary open-angle glaucoma. 


\section{REFERENCES}

1. Agnifili, L., Pieragostino, D., Mastropasqua, A., Fasanella, V., et al. 2015. Molecular biomarkers in primary open-angle glaucoma: from noninvasive to invasive. Progress in Brain Research. Volume 221. Amsterdam, Oxford, Waltham: Elsevier B.V., 1-32. ISBN 0079-6123.

2. Aydin, A., Wollstein, G., Price, L.L., Fujimoto, J.G., Schuman, J.S. 2003. Optical coherence tomography assessment of retinal nerve fiber layer thickness changes after glaucoma surgery. Ophthalmology. 110(8), 1506-1511.

3. Akashi, A., Kanamor, A., Nakamura, M., et al. 2013. Comparative Assessment of the Ability of Cirrus, RTVue, and 3D-OCT to Diagnose Glaucoma. Invest Ophthal Vis Sci. 54, 4478-4484.

4. Alexandrescu, C., Dascalu, A.M., Mitulescu, C., Panca, A., Pascu, R., Ciuluvica, R., Potop, V., Voinea, L.M. 2010. Evidence-based pathophysiology of glaucoma. Medica A Journal of Clinical Medicine. 5(3), 207-213.

5. Alvarado, J.A., Yeh, R.F., Franse-Carman, L., Marcellino, G., Brownstein, M.J. 2005. Interactions between endothelia of the trabecular meshwork and of Schlemm's canal: a new insight into the regulation of aqueous outflow in the eye. Trans Am Ophthalmol Soc. 103, 148-162, discussion, 162-143.

6. Ausekle, S. 05.12.2015. Redzes lauks un invaliditātes ekspertīze (Eng. Field of vision and disability expertise). 9.VDE $\bar{A} K$.

7. Azuara-Blanco, A., Spaeth, G.L. 1997. Methods to objectify reversibility of glaucomatous cupping. Curr Opin Ophthalmol. 8(2), 50-54.

8. Bertrand, V., Fieuws, S., Stalmans, I., Zeyen, T. 2014. Rates of visual field loss before and after trabeculectomy. Acta Ophthalmologica. 2, 116-120.

9. Buys, E.S., Zimmer, D.P., Chickering, J., Graul, R., Chien, Y.T., Profy, A., Hadcock, J.R., Masferrer, J.L., Milne, G.T. 2018. Discovery and development of next generation sGC stimulators with diverse multidimendional pharmacology and broad therapeutic potential. Nitric Oxide. 78, 72-80.

10. Centrālā Statistikas Pārvalde. 2018. Demogrāfija. Statistisko datu krājums (Eng. Central Statistical Bureau of Latvia. Demography. Satistical data collection). Rīga, 18. ISSN 2501-0034

11. Chang, P.T., Sekhon, N., Budenz, D.L., Feuer, W.J., Park, P.W., Anderson, D.R. 2007. Effect of lowering intraocular pressure on optical coherence tomography measurement of peripapillary retinal nerve fiber layer thickness. Ophthalmology. $114,488-493$.

12. Coleman, A.L., Quigley, H.A., Vitale, S., Dunkelberger, G. 1991. Displacement of the optic nerve head by acute changes in intraocular pressure in monkey eyes. Ophthalmology. 98, 35-40.

13. Diestelhorst, M., Krieglstein, G.K. 1989. The intraocular pressure response of human atrial natriuretic factor in glaucoma. Int Ophthalmol. 13(1-2), 99-101.

14. Duan, X., Lu, Q., Xue, P., Zhang, H., Dong, Z., Yang, F., Wang, N. 2008. Proteomic analysis of aqueous humor from patients with myopia. Mol Vis. 14, 370377.

15. Ekstrom, C. 2012. Risk factors for incident open-angle glaucoma: a populationbased 20-year follow-up study. Acta Ophthalmol. Jun, 90(4), 316-321. 
16. European Glaucoma Society. 2014. Terminology and Guidelines for Glaucoma, 4rd ed. Savona, Italy: Editrice DOGMA, 36, 37, 51, 75-119, 170. ISBN 978-8898320-05-9

17. Fernandez, M.J., Leal, M.A., Guzman, J. 2010. Appropriateness of treating glaucoma suspects. Concordancy study with the RAND study group. Arch Soc Esp Oftalmol. 85(5), 174-178.

18. Fernandez-Durango, R., Moya, F.J., Ripodas, A., DeJuan, J.A., Fernandez-Cruz, A., Bernal, R. 1999. Type B and type C natriuretic peptide receptors modulate intraocular pressure in the rabbit eye. Eur J Pharmacol. 364, 107-113.

19. Flammer, J., Konieczka, K., Bruno, R.M, Virdis, A., Flammer, A.J., Taddei, S. 2013. The eye and the heart. European Heart Journal. 34, 1270-1278.

20. Fuchshofer, R., Tamm, E.R. 2009. Modulation of extracellular matrix turnover in the trabecular meshwork. Exp Eye Res. 88, 683-688.

21. Goldmann, D.B., Waubke, N. 1989. A pilot study on the effect of atrial natriuretic peptide on intraocular pressure in the human. Fortschr Ophthalmol. 86(5), 494496.

22. Harju, M., Saari, J., Kurvinen, L., Vesti, E. 2008. Reversal of optic disc cupping in glaucoma. Br J Ophthalmol. 92(7), 901-905.

23. Heijl, A., Leske, M.C., Bengtsson, B., Hyman, L., Bengtsson, B., Hussein, M. 2002. Early Manifest Glaucoma Trial Group. Reduction of intraocular pressure and glaucoma progression: results from the Early Manifest Glaucoma Trial. Arch Ophthalmol. 120(10), 1268-1279.

24. Heijl, A., Bengtsson, B., Hyman, L., Leske, M.C. 2009. The Early Manifest Glaucoma Trial Group. Natural History of Open-Angle Glaucoma. Ophthalmology. 116(12), 2271-2276.

25. Yang, H., Thompson, H., Roberts, M.D., Sigal, I.A., Dows, J.C., Burgoyne, C.F. 2011. Deformation of the early glaucomatous monkey optic nerve head connective tissue after acute IOP elevation in 3-D histomorphometric reconstructions. Invest Ophthalmol Vis Sci. 52, 345-363.

26. Irak, I., Zangwill, L., Garden ,V., Shakiba, S., Weinreb, R.N. 1996. Change in optic disc topography after trabeculectomy. Am J Ophthalmol. 122, 690-695.

27. Yuen, D., Buys, Y.M. 2010. Disc photography and Heidelberg retinal tomography documentation of reversal of cupping following trabeculectomy. Graefes Arch Clin Exp Ophthalmol. 248(11), 1671-1673.

28. Jonas, J.B., Nguyen, X.N., Gusek, G.C., Naumann, G.O. 1989. Parapapillary chorioretinal atrophy in normal and glaucoma eyes. I. Morphometric data. Invest Ophthalmol Vis Sci. 30(5), 908-918.

29. Katz, L.J., Spaeth, G.L., Cantor, L.B., Poryzees, E.M., Steinmann, W.C. 1989. Reversible optic disk cupping and visual field improvement in adults with glaucoma. Am J Ophthalmol. 107(5), 485-492.

30. Knepper, P.A., Kelsey, A.G., Samples, J.R. 2016. Glaucoma Research and Clinical Advances: 2016 to 2018. Amsterdam: The Netherlands. Kugler Publications. 99106. ISBN 978-90-6299-247-8.

31. Kotecha, A., Siriwardena, D., Fitzke, F.W., Hitchings, R.A., Khaw, P.T. 2001. Optic disc changes following trabeculectomy: longitudinal and localisation of change. Br J Ophthalmol. 85(8), 56-61. 
32. Kotecha, A., Spratt, A., Bunce, C, Garway-Heath, D.F., Khaw, P.T., Viswanathan, A. 2009. Optic disc and visual field changes after trabeculectomy. Invest Ophthalmol Vis Sci. 50(10), 4693-4699.

33. Kotikoski, H., Alajuuma, P., Moilanen, E., Salmenpera, P., Oksala, O., Laippala, P., et al. 2002. Comparison of nitric oxide donors in lowering intraocular pressure in rabbits: role of cyclic GMP. J Ocul Pharmacol Ther.18, 11-23.

34. Kotikoski, H., Vapaatalo, H., Oksala, O. 2003. Nitric oxide and cyclic GMP enhance aqueous humor outflow facility in rabbits. Curr EyeRes. 26, 119-123.

35. Lamping, K.A., Bellows, A.R., Hutchinson, B.T., Afran, S.I. 1986. Long-term evaluation of initial filtration surgery. Ophthalmology. 93(1), 91-101.

36. Lee, K.Y., Tomidokoro, A., Sakata, R., et al. 2010. Cross-sectional anatomic configurations of peripapillary atrophy evaluated with spectral domain-optical coherence tomography. Invest Ophthalmol Vis Sci. 51, 666-671.

37. Lesk, M.R., Spaeth, G.L., Azuara-Blanco, A., Araujo, S.V., Katz, L.J., Terebuh, A.K., Wilson, R.P., Moster, M.R., Schmidt, C.M.1999. Reversal of optic disc cupping after glaucoma surgery analysed with a scanning laser tomograph. Ophthalmology. 106(5), 1013-1018.

38. Leske, M.C., Heijl, A., Hussein, M., Bengtsson, B., Hyman, L., Komaroff, E. 2003. Factors for glaucoma progression and the effect of treatment: the early manifest glaucoma trial. Arch. Ophthalmol. 121(1), 48-56.

39. Liu, Y., Garrett, M.E., Yaspan, B.L., et al. 2014. DNA Copy Number Variants of Known Glaucoma Genes in Relation to Primary Open-Angle Glaucoma. Invest Ophthalmol Vis Sci. 55(12), 8251-8258.

40. Manjunath, V., Shah, H., Fujimoto, J.G., Duker, J.S. 2011. Analysis of peripapillary atrophy using spectral domain optical coherence tomography. Ophthalmology. 188, 531-536.

41. Miglior, S., Pfeiffer, N., Torri, V., Zeyen, T., Cunha-Vaz, J., Adamsons, I. 2007. Predictive factors for open angle glaucoma among patients with ocular hypertension in the European Glaucoma Prevention Study. Ophthalmology. 114(1), 3-9.

42. Mills, R.P., Budenz, D.L., Lee, P.P., Noecker, R.J., Walt, J.G., Siegartel, L.R., Evans, S.J., Doyle, J.J. 2006. Categorizing the stage of glaucoma from prediagnosis to end-stage disease. Am J Ophthalmol. 141(1), 24-30.

43. Mwanza, J.C., Oakley, J.D., Budenz, D.L., et al. 2011. Ability of cirrus HD-OCT optic nerve head parameters to discriminate normal from glaucomatous eyes. Cirrus Optical Coherence Tomography Normative Database Study Group. Ophthalmology. 118, 241-248.

44. Na, J.H., Moon, B.G., Sung, K.R., Lee, Y., Kook, M.S. 2010. Charecterization of peripapillary atrophy using spectral domain optical coherence tomography. Korean J Ophthalmol. 24, 353-359.

45. Nicolela, M.T., Soares, A.S., Carrillo, M.M., Chauhan, B.C., LeBlanc, R.P., Artes, P.H. 2006. Effect of moderate intraocular pressure changes on topographic measurements with confocal scanning laser tomography in patients with glaucoma. Arch Ophthalmol. 124(5), 633-640.

46. Panda-Jonas, S., Xu, L., Yang, H., Wang, Y.X., Jonas, S.B., Jonas, J.B. 2014. Optic nerve head morphology in young patients after antiglaucomatous filtering surgery. Acta Ophthalmol. 92, 59-64. 
47. Park, K.H., Kim, D.M., Youn, D.H. 1997. Short-term change of optic nerve head topography after trabeculectomy in adult glaucoma patients as measured by Heidelberg retina tomograph. Korean J Ophthalmol. 11(1), 1-6.

48. Parrish, R.K. $2^{\text {nd }}$, Feuer, W.J., Schiffman, J.C., Lichter, P.R., Much, D.C., CIGTS Optic Disc Study Group. 2009. Five-year follow-up optic disc findings of the Collaborative Initial Glaucoma Treatment Study. Am J Ophthalmol. 147(4), 717724.e1.

49. Pierro, L., Gagliardi, M., Iuliano, L., et al. 2012. Retinal nerve fiber layer thickness reproducibility using seven different OCT instruments. Invest Ophthal Vis Sci. 53, 5912-5920.

50. Poostchi, A., Wong, T., Chan, K.C., Kedzlie, L., Sachdev, N., Nicholas, S., Garway-Heath, D.F., Wells, A.P. 2010. Optic disc diameter increases during acute elevations of intraocular pressure. Invest Ophthalmol Vis Sci. 51(5), 2313-2316.

51. Quigley, H.A., Broman, A.T. 2006. The number of people with glaucoma worldwide in 2010 and 2020. Br J Ophthalmol. 90(3), 262-267.

52. Quigley, H.A., McKinnon, S.J., Zack, D.J., et al. 2000. Retrograde axonal transport of BDNF in retinal ganglion cells is blocked by acute IOP elevation in rats. Invest Ophthalmol Vis Sci. 41, 3460-3466.

53. Quigley, H.A. 1999. Neuronal death in glaucoma. Prog Retin Eye Res.18,39-57.

54. Raghu, N., Pandav, S.S., Kaushik, S., Ichhpujani, P., Gupta, A. 2012. Effect of trabeculectomy on RNFL thickness and optic disc parameters using optical coherence tomography. Eye (Lond). 26(8), 1131-1137.

55. Rebolleda, G.,Muñoz-Negrete, F.J., Noval, S. 2007. Evaluation of changes in peripapillary nerve fiber layer thickness after deep sclerectomy with optical coherence tomography. Ophthalmology. 114(3), 488-493.

56. Reis, A.S., Sharpe, G.P., Yang, H., Nicolela, M.T., Burgoyne, C.F., Chauhan, B.C. 2012. Optic disc margin anatomy in patients with glaucoma and normal controls with spectral domain optical coherence tomography. Ophthalmology. 119, 738747.

57. Salzmann, J., Flitcroft, D., Bunce, C., Gordon, D., Wormald, R., Migdal, C. 1998. Brain natriuretic peptide: identification of a second natriuretic peptide in human aqueous humour. Br J Ophthalmol. 82(7), 830-834.

58. Sarkar, K.C., Das, P., Pal, R., Shaw, C. 2014. Optical coherence tomogrphic assessment of retinal fiber layer thickness changes before and after glaucoma filtration surgery. Oman J Ophthalmol. 7, 3-8.

59. Sung, K.R., Wollstein, G., Kim, N.R., et al.2012. Macular assessment using optical coherence tomography for glaucoma diagnosis. Br J Ophthalmol. 96, 1452-1455.

60. Tanna, A.P., Johnson, M. 2018. Rho kinase inhibitors as a novel treatment for glaucoma and ocular hypertension. Ophthalmology. 125, 1741-1756.

61. Tham, Y-C., Li, X., Wong, T.Y., Quigley, H.A., Aung, T., Cheng C-Y. 2014. Global Prevalence of Glaucoma and Projections of Glaucoma Burden through 2040. Ophthalmology. 121(11), 2081-2090.

62. Topouzis, F., Peng, F., Kotas-Neumann, R., Garcia, R., Sanguinet, J., Yu, F., Coleman, A.L. 1999. Longitudinal changes in optic disc topography of adult patients after trabeculectomy. Ophthalmology. 106(6), 1147-1151.

63. Wareham, L.K., Buys, E.S., Sappington, R.M. 2018. The nitric oxide-guanylate cyclase pathway and glaucoma. Nitric Oxide. 77, 75-87. 
64. Wittström, E., Schatz, P., Lövesta-Adrian, M., Ponjavic, V., Bergström, A., Andreasson, S. 2010. Improved retinal function after trabeculectomy in glaucoma patients. Graefes Arch Clin Exp Ophthalmol. 248, 485-495.

65. Wolfensberger, T.J., Singer, D.R., Freegard, T., Markandu, N.D., Buckley, M.G., MacGregor, G.A. 1994. Evidence for a new role of natriuretic peptides: control of intraocular pressure. Br J Ophthalmol. 78, 446-448.

66. Zāḷu valsts aǵentūra. Zāḷu patēriņa statistika 2017 (Eng. State Agency of Medicines. Medication Consumption Statistics 2017). Zāļu valsts aǵentūra. 2018. p. 53, [Tiešsaiste] Pieejams: https://www.zva.gov.lv/sites/default/files/201805/zva-zstat-2017.pdf [sk. 05.05.2017.]. 


\section{LIST OF PUBLICATIONS}

\section{Published scientific articles}

1. Aitullina, A., Baumane K., Zalite, S., Ranka, R., Zole, E., Pole, I., Sepetiene, S., Laganovska, G., Baumanis, V., Pliss, L. Point mutations associated with Leber hereditary optic neuropathy in a Latvian population. Molecular Vision. 2013 Nov 21; 19:2343-2351. eCollection 2013

2. Baumane, K., Laganovska, G., Pliss, L. Atrial natriuretic paptide gene and plasma pro-ANP concentration in patients with primary open-angle glaucoma. Proceedings of the Latvian Academy of Sciences, section B, Vol. 62, 2008, No 6(659), 193-198.

3. Baumane, K., Ranka, R., Laganovska, G. The effect of glaucoma filtration surgery on structural and functional eye parameters in short-term study. Proceedings of the Latvian Academy of Sciences. Section B, Vol. 71, 2017, No. 1/2 (706/707), pp.2732. DOI: 10.151/prolas-2017-0005

4. Baumane, K., Ranka, R., Laganovska, G. Association of NT-proANP Level in Plasma and Humor Aqueous with Primary Open-Angle Glaucoma. Current Eye Research. 2017, Feb; 42(2), 233-236. doi: 10.1080/02713683.2016.1180397. Epub 2016 Oct 10

5. Egorov, E., Erichev, V., Astakhov, Y., Alekseev, V., Takhchidi, K., Zhaboedov, G., Eugeny, E., Eugeny, A., Staritskaya, T. V., Evgenevna, E. T., Borisovna, R.,T., Sheremetyeva, S., Oganezova, J.,G., Petrovich, E.,V., Vagizona, Y.,L., Sergueevich, A.,Y., Alekseevna, D.,G., Borisovna, L.,A., Kasimovna, A., Victorovich, P.,A., Alexeev, V., Levko, M., Martynova, E., Kolotov, A., Mironova, E.,M., Proshina, O.,I., Kozlova, E.,E., Sochinskaya, V.,K., Grishina, T.,S., Zhaboedov, G.,D., Petrenko, O.,V., Tymoshenkova, O.,V., Vitovska, O.,P., Kurilina, O.,I., Parkhomenko, O.,G., Pasechnokova, N.,V., Korol, A.,R., Klyuev, G.,O., Romodanova, K.,S., Nevska, A., Padanevych, E., Kaljurand, K., Pastak, M., Seljagina, N., Palumaa, K., Somma, K., Laganovska, G., Baumane, K. Adjunctive use of tafluprost with timolol provides additive effects for reduction of intraocular pressure in patients with glaucoma. Eur J Ophthalmol. 2009 Mar-Apr;19(2), 214222.

6. Gandolfi, S., Paredes, T., Goldberg, I., Coote, M., Wells, A., Volksone, L., Pillai, M,.R., Stalmans, I., Denis, P., Clinical Study Group (Baumane, K.) Comparison of a travoprost BAK-free formulation preserved with polyquaternium-1 with BAKpreserved travoprost in ocular hypertension or open-angle glaucoma. Eur $\mathrm{J}$ Ophthalmol. 2012 Jan-Feb:22(1), 34-44. doi:10.5301/ejo.5000001.

\section{Abstract and participation in Congresses and Conferences}

1. Baumane, K. Association of NT-proANP Level in Plasma and Aqueous Humor with Primary Open-Angle Glaucoma. International Ophthalmology Conference OphthalmicHub 2019. Kiev, Ukraine. March 15, 2019. Oral presentation.

2. Baumane, K., Laganovska, G., Pliss, L., Krūmiņa, A., Brakmanis, A. Confirmed family case of Leber's hereditary optic neuropathy. XIII Forum Ophthalmologicum 
Balticum, August 20-22 nd, 2010 , Vilnius, Lithuania. Abstract book, p. 92. Poster presentation.

3. Baumane, K., Aitullina, A., Zalite, S., Laganovska, G., Ranka, R., Sepetiene, S., Pliss, L. Point mutations associated with Leber hereditary optic neuropathy in a Latvian population. DOG 2014, Deutshe Ophthalmologische Gesellschaft 112. DOG-Kongress, 25.-28.09.2014., Leipzig, Germany, p.141. Poster presentation.

4. Baumane, K., Aitullina, A., Zalite, S., Pliss, L., Kimsis, J., Pole, I., Sepetiene, S., Laganovska, G., Baumanis, V. With Leber hereditary optic neuropathy associated common and rare point mutations in Latvian population. SOE 2013, 19th Congress of the European Society of Ophthalmology Copenhagen, Denmark, June 8-11, 2013, p.74. Poster presentation.

5. Baumane, K., Aitullina, A., Zalite, S., Pliss, L., Sepetiene, S., Laganovska, G., Baumanis, V. With Leber hereditary optic neuropathy associated common and rare point mutations in Latvian population. XIV Forum Ophthalmologicum Balticum, August 23-24, 2013, Tallinn, Estonia. p.85. Poster presentation.

6. Baumane, K., Dambite, G., Laganovska, G. Glaucoma Patients Dry Eye Syndrome. IX Baltic Congress of Ophthalmology \& Optometry, Riga, Latvia, October 2-4, 1998, p.44, Oral presentation.

7. Baumane, K., Laganovska, G., Meškovska, L., Ranka, R. Analysis of genetic polymorphisms in operated primary open angle glaucoma patients in Latvian population. SOE 2017 Congress, June 10-13, 2017, Barcelona, Spain. Electronic poster A-874-0007-00677.

8. Baumane, K., Laganovska, G., Meškovska, L., Ranka, R. Analysis of genetic polymorphisms in operated primary open angle glaucoma patients in Latvian population. WGC 2017, 7th World Glaucoma Congress, Helsinki, Finland, June 28-July 1, 2017. Poster presentation and oral presentation. WGCSUB-1337.

9. Baumane, K., Laganovska, G. The influence of antiglaucoma operation on structural and functional properties of $O N H$ and RNFL. XII Forum Ophthalmologicum Balticum. August 24-26, 2007, Riga, Latvia, p.66. Oral presentation.

10. Baumane, K., Laganovska, G. Outcomes of post-penetrating keratoplasty glaucoma surgery. XIV Forum Ophthalmologicum Balticum, August 23-24, 2013, Tallinn, Estonia. p.36. Oral presentation.

11. Baumane, K., Laganovska, G. The importance of atrionatriuretic peptide in detection of glaucoma progression. The 1 st Baltic Glaucoma Expert meeting, February 1-2, 2008, Riga, Latvia. Oral presentation.

12. Baumane, K., Laganovska, G. The influence of Antiglaucoma Operation on Structural and Functional Properties of ONH and RNFL and pro ANP (Atrial Natriuretic Peptide) Level in the Blood Plasma. WOC 2008, World Ophthalmology Congress, Hong Kong, June 28-July 2, 2008, Clinical \& Experimental Ophthalmology, Volume 36, Supplement 1, June 2008, ISSN 1442-6404, p. A236, Poster No GC-D2-178, Panel No 178. Poster presentation.

13. Baumane, K., Laganovska, G., Meškovska, L., Ranka, R. Analysis of genetic polymorphisms in operated primary open angle glaucoma patients in Latvian population. XV Forum Ophthalmologicum Balticum, August 19-21, 2016, Riga, Latvia, p.42. Oral presentation. 
14. Baumane, K., Laganovska, G., Ranka, R. Pro-ANP (atrial natriuretic peptide) concentration differences in aqueous humor and plasma in open-angle glaucoma (OAG) patients compared with cataract patients (CP). 10 th EGS European Glaucoma Society Congress, Copenhagen, June 17-22, 2012, p. 51. E-poster presentation.

15. Baumane, K., Meskovska, L., Laganovska, G., Ranka, R. Analysis of genetic polymorphisms in Latvian patients with primary open angle glaucoma. DOG 2016, Deutshe Ophthalmologische Gesellschaft 114. DOG-Kongress, September 29October 2, 2016, Berlin, Germany, p.135. Poster presentation.

16. Baumane, K., Pliss, L. Increase of the Plasma Proatrial Natriuretic Peptide in Primary Open Angle Glaucoma. X Forum Ophthalmologicum Balticum, October 25-27, 2001, Vilnius, Lithuania. Oral presentation.

17. Baumane, K., Pliss, L. Primary open angle glaucoma (POAG) and natriuretic peptides as citeria of ocular ischemia. SOE 2003, 14th Congress of the European Society of Ophthalmology, Madrid, Spain, June 7-12, 2003, p.179. Poster presentation.

18. Baumane, K., Ranka, R., Laganovska, G. ANP - atrial natriuretic peptide concentration differences in aqueous humour and plasma in open-angle glaucoma patients compared with cataract patients. NOK 2012, XXXX Nordic Congress of Ophthalmology, August 24-28, 2012, Paasitorni, Helsinki, Finland. Abstract book, p. 66. Oral presentation.

19. Baumane, K., Ranka, R., Laganovska, G. Pro ANP (atrial natriuretic peptide) concentration differences in aqueous humor and plasma in Open-Angle Glaucoma patients compare with cataract patients. WOC 2012, World Ophthalmology Congress, Abu Dhabi, United Arab Emirates, February 16-20, 2012. Poster presentation.

20. Baumane, K., Ranka, R., Laganovska, G. Pro ANP (Atrial natriuretic peptide) concentration differences in aqueous humor and plasma in open angle glaucoma $(O A G)$ patients compare with cataract patients (CP). XIV Forum Ophthalmologicum Balticum, August 23-24, 2013, Tallinn, Estonia. p.75. Poster presentation.

21. Baumane, K., Ranka, R., Laganovska, G. Pro ANP (Atrial natriuretic peptide) concentration differences in aqueous humor and plasma in open angle glaucoma $(O A G)$ patients compare with cataract patients $(C P)$. XXXI Congress of the ESCRS, October 5-9, 2013, Amsterdam, p.128. E-poster presentation.

22. Baumane, K., Ranka, R., Laganovska, G. The influence of glaucoma surgery on the structural and functional eye parameters in different glaucoma stages. SOE 2015, 20th Congress of the European Society of Ophthalmology Vienna, Austria, June 6-9, 2015, p.76, EP-GLA-0427. Electronic poster presentation.

23. Drucka, E., Borroni, D., Valeina, S., Viksnins, M., Sperga, V., Treija, A., Baumane, K., Laganovska, G. Long-Term Outcomes of Trabeculectomy Undertaken within the First 2 Years of Life for Primary Congenital Glaucoma. SOE 2017 Congress, 10-13 June, Barcelona, Spain. Electronic poster.

24. Drucka, E., Borroni, D., Valeina, S., Viksnins, M., Sperga, V., Treija, A., Baumane, K., Laganovska, G. Assessment of Primary Congenital Glaucoma in Latvia. WGC 2017, 7th World Glaucoma Congress, Helsinki, Finland June 28-July 1, 2017. Poster presentation. WGCSUB-2035. 
25. Pliss, L., Baumane, K., Laganovska, G., Aitullina, A., Krūmiņa, A. Genetic analysis of the mitochondrial DNA (mtDNA) in patients with ocular pathology. 36th FEBS (Federation of European Biochemical Societies) Congress, Torino, Italy, June 25-30, 2011. The FEBS Journal, June, Volume 278 (Suppl.1) 74-445, 2011, ISSN 1742-464X, p.254-255. Poster presentation.

26. Pliss, L., Laganovska, G., Baumane, K., Brakmanis, A., Krūmiņa, A. Confirmed family case of Leber's hereditary optic neuropathy. Proceedings of the Latvian Academy of Sciences, Section B, Vol.61, 2007, No.5., p.176. Abstracts of the IV Baltic Genetical Congress.

27. Ranka, R., Gustina, A., Baumane, K., Pliss, L., Laganovska, G., Baumanis, V. The study of genetic factors in primary open-angle glaucoma patients in Latvia. FEBS J. 2012 Sep, 279 Suppl 1, 1-598. doi: 10.1111/j.1742-4658.2010.08701.x. Abstracts of the 22nd IUBMB \& 37th FEBS Congress, Sevilla (Spain), September 4-9, 2012. Poster presentation.

28. Baumane, K., Laganovska, G. Antiglaukomatozas operācijas ietekme uz acs strukturālajiem un funkcionālajiem rādìtājiem, to saistība ar pro-ANP (ātrija nātrijurētiskā peptīda) lìmeni asins plazmā (Eng. Impact of antiglaucomatous surgery on structural and functional parameters of the eye, their relation to plasma levels of pro-ANP (sodium natriuretic peptide). RSU zinātniskās konferences tēzes. 2008. gada 13. un 14. martā, 64. lpp, mutiskā uzstāšanās.

29. Baumane, K., Pliss, L. Átrija nātrijurētiskā peptīda (ANP) saistība ar primāru atverta kakta glaukomu (Eng Relationship of atrial natriuretic peptide (ANP) to primary open-angle glaucoma). RSU zinātniskās konferences tēzes. 2003. gada 7. martā, 129. lpp, mutiskā uzstāšanās.

30. Baumane, K., Ranka, R., Laganovska, G. Antiglaukomatozas operācijas ietekme uz acs strukturālajiem un funkcionālajiem parametriem dažādu glaukomas stadiju gadijumos (Eng. Impact of antiglaucomatous surgery on structural and functional parameters of the eye in different stages of glaucoma). RSU zinātniskās konferences tēzes. 2015. gada 26. un 27. martā, p. 10. Oral presentation.

31. Baumane, K., Ranka, R., Laganovska, G. Pro-ANP (atrial natriuretic peptide) Concentration Differences in Aqueous Humor and Plasma in Open-angle Glaucoma (OAG) Patients Compared with Cataract Patients (CP). RSU zinātniskās konferences tēzes. 2012. gada 29. un 30. martā, p. 116. Oral presentation.

32. Krūmiņa, A., Laganovska, G., Baumane, K., Pliss, L., Brakmanis, A., Lāce, B., Krūmiņa, Z., Baumanis, V. Mitohondriālās DNS analīze cilvēka patologijas diagnostikā (Eng. Mitochondrial DNA analysis in human pathology diagnostics). RSU zinātniskās konferences tēzes. 2008. gada 13. un 14. martā, 102. lpp. 


\section{ACKNOWLEDGEMENTS}

The author of the Thesis expresses great gratitude to the supervisor of the Doctoral Thesis Professor Guna Laganovska for the given opportunity to develop and defend the Doctoral Dissertation, as well as for the encouragement of other scientific activities.

The author of the Thesis is very grateful to Professor Aivars Lejnieks for valuable advice and support during the creation of the work.

The author expresses profound gratitude to Associated Professor Renate Ranka for the scientific support provided and for assisting in the processing of the research material.

The author expresses her deepest gratitude to her family for their strength, understanding, and invaluable support during the development of the Doctoral Thesis. 